\title{
The (Un-)Importance of Generational Dialogue in Georgian Political Tradition
}

Keywords: generational dialogue, Georgia, young generation, Georgian society, political tradition

\begin{abstract}
The aim of this paper is to examine the importance of generational dialogue in the Georgian political tradition. The research statement of this paper is that the generational dialogue in Georgia, which is not particularly rooted in the political tradition, is currently flat and unconstant. In addition, due to the current situation of Georgia related to the democratization of the state, a new chapter for Georgian generational dialogue can be opened. To analyze this research problem, I have used a number of research methods based partly on secondary and primary sources, i.e. expert interviews were conducted online with Georgian researchers from the Ivane Javakhivshvili Tbilisi State University and Ilia State University. The paper is a snapshot of the theory of generational dialogue, and it presents the work of Polish scientists. Moreover, it examines the generational dialogue in the post-Soviet area, and this analysis can be developed in further scientific publications. The study of generational dialogue is essential for analyzing the perception of democracy and democratization among the generations in Georgia.
\end{abstract}

* ORCID ID: https://orcid.org/0000-0003-4451-5092; assistant at the Institute of Political Science and International Relations at Collegium Civitas, Poland. Email: katarzyna.skiert@ gmail.com. 


\section{Preliminary Remarks and Research Methodology}

After proclaiming independence, Georgia faced a difficult choice of a socio-political transformation model. The more so because the historical and cultural conditions have influenced the ethnopolitical complexity of the state. Moreover, the Soviet legacy did not facilitate this choice and ultimately, cultural and geographical proximity to Europe directed Georgia to choose a social and political transformation based on the Western democratic system, and to a large extent on the European model.

According to G. Nodia, already in 1918-1921, the main "political project" ${ }^{1}$ of Georgia was defined. This project was based on the assumption that Europe would provide Georgia with a greater identity based on Western patterns, while giving the society a sense that Europe is its ally. This meant, as I intend to emphasize, that Georgian society had the impression that it was an integral part of European civilization and that Georgia should ally with the West to build a democratic state ${ }^{2}$.

In the 1990s, pro-European aspirations of Georgia revived on the wave of independence, and prior assumptions of the "political project" became the foundation for choosing a model of political and social transformation based on building a democratic state. Thus, the pro-EU orientation gradually began to supplant the pro-Russian orientation.

This transformation of socio-political orientation derives from the idea of "Europeanism" that became popular in Georgia as far back as the $18^{\text {th }}$ century. The well-known Georgian writer and journalist Iakob Gogebashvili wrote in the $19^{\text {th }}$ century that " $(.$.$) since the 18^{\text {th }}$ century the entire nation has felt the need to bring Europe closer” [own translation] ${ }^{3}$. In 1918, after

1 G. Nodia uses the term "political project" in the sense that the state and the nation are a "quasi-personality," which needs a goal around which the efforts and actions of those in power focus. Understanding of the "political project" underlies what is usually understood by "national interest"; without confusing this concept with a "national project" that reflects the ambitions of various people (or their elites), as well as political values, ideologies, and orientations prevailing in society. People can create countries that try to play an active role in shaping the world, or they can simply choose as "consumers" of public goods produced within the international order. They can try to create a "nation state" for a particular nation; or they may think that the unification of different "nations" is the task of their state; G. Nodia, Components of the Georgian National Idea: An Outline, «Identity Studies» 1 (1), pp. 84-101; G. Nodia, Georgia: Dimensions of Insecurity, [in:] R. Legvold, B. Coppieters (eds.), Statehood and Security: Georgia after the Rose Revolution, Cambridge 2005, p. 41.

2 K. Skiert-Andrzejuk, Georgia's Political Brand in the European Union: Building the Political Product and the Political Brand, «Nowa Polityka Wschodnia» 2018, vol. 4, iss. 19, pp. 77-90.

3 B. Chedia, Georgia on the political map of Europe: new geopolitical realities, «Central Asia and the Caucasus» 2010, no. 11 (1), pp. 19-28. 
Georgia broke away from the Russian Empire, it chose Germany as its ally, but only to discover that the alliance was too fragile to exist. Germany did not help Georgia in the fight against the Soviet occupiers. And so, Georgia for many years lost the chance to improve its relations with Europe ${ }^{4}$.

The second factor that affected the idea of "Europeanism" was religion - Christianity. It can be considered as a significant common element binding Georgia and Europe. Christianity has set the direction of Georgia's external policy. Moreover, the faith was and still is an important part of Georgian social and cultural life $e^{5}$.

It should be emphasized, however, that in Georgia, as in other post-Soviet states that have entered the path of democratic change, there is still a divergence in opinions on the chosen model of political transformation and on a pro-European orientation. Building democracy in Georgia is largely based on the implementation of European standards of democracy and Georgian interpretation and implementation of these standards and principles. According to W. Jagielski, in Georgia and, more broadly, in the Caucasus, "democracy was the »embodiment « of all good and of virtues and the bright future that everyone looked at. It seemed that the very word »democracy«, loud and often repeated, would turn out to be a magic formula that would wonderfully change reality" [own translation] ${ }^{6}$.

Therefore, the political, economic and cultural environment of Georgia has changed over the past three decades. First, a new generation of Georgians was born. Moreover, the changes in the economic sphere, opening up to the international community, establishing cooperation under new projects, initiatives and organizations, technological progress, access to information through free media, the Internet and social media were also of great importance. All these factors caused the crossing of national and traditional social barriers and the change of narrative within the framework of the generational dialogue, which revealed and highlighted the differences in generations.

This paper wants to provide a little food for thought about the notion of generational dialogue and to pave the way towards the youth in the post-Soviet space as part of a future research agenda. The study will sketch out the issue of generational existence in Georgia and it can be considered particularly important: first, due to the current democratiza-

4 B. Chedia, Georgia: The Long Journey from the Byzantine Empire to the European Union, http://www.eastbook.eu/en/2012/01/09/georgia-the-long-journey-from-the-byzantineempire-to-the-european-union (1.05.2020).

5 K. Skiert-Andrzejuk, Georgia's Political Brand..., pp. 77-90.

6 W. Jagielski, Dobre miejsce do umierania, Warsaw 2008, pp. 27-28. 
tion of Georgia the results of these studies may contribute to further research on democracy and understanding democracy from the "bottom-up." Second, the studied issues fill the research gap on young people in the post-Soviet states and young people in Georgia. The study is part of a series of papers on the opinion of the young generation of Georgians about democracy and democratization. Third, in the case of those states that are currently undergoing democratization, like Georgia, there is uncertainty whether the choice was correct in the face of the crisis of democratic legitimacy, and one of the elements affecting this crisis is the individual factor in the form of flat and unconstant generational dialogue, and more broadly in intergenerational relationships.

The research statement of this paper is that the generational dialogue in Georgia, which is not particularly rooted in the political tradition, is currently flat and unconstant. In addition, due to the current situation of Georgia related to the democratization of the state, a new chapter for Georgian generational dialogue can be opened.

To analyze this research problem, I have used a number of research methods based partly on secondary and primary sources. The basic research methods used in the paper are the existing data analysis method, desk research, in which a scientific query was made - this method was aimed at analyzing the literature on the definition of dialogue and generational dialogue. In addition, the method was supported by a method of qualitative analysis with the technique of expert interview. Expert interviews were conducted online with Georgian researchers from the Ivane Javakhivshvili Tbilisi State University and Ilia State University.

The paper paves the way towards the youth in the post-Soviet space as part of a future research agenda, and it organizes and presents the work of Polish scientists on the notion of generational dialogue. The analysis of generational dialogue is essential for analyzing the reception of democracy and democratization among the generations in Georgia.

\section{Generational Dialogue and Political Tradition: Theoretical Framework and Discussion}

Generational dialogue begins in the family sphere, and as a special type of interpersonal communication ${ }^{7}$ at a social level, it emerges as

7 Interpersonal communication consists in providing information in verbal and nonverbal language. This is a special process shaping the social behavior of individuals. The origins of communication should be sought in the family, where it is the main carrier and com- 
a fundamental category. First of all, it normalizes and enriches relationships between people, between generations. The very word "dialogue" comes from the Greek dialogos and means the conversation of two people. According to M. Śnieżyński, dialogue is "(...) a mutual exchange of thoughts of at least two people, in which the roles of the sender and the recipient are interchangeable with full respect for the right to their own views, in order to get to know each other and understand each other" [own translation $]^{8}$. Thus, the content of a dialogue is the expression of one's own opinions, and what is more, it is not only through words, but also through actions. In a dialogue ${ }^{9}$ according to J. Grzybowski, one does not impose one's opinions, but it is passed onto the other party, while the parties' goal is not to convince each other, but to convey this difference. In addition, J. Grzybowski develops the definition of dialogue, namely, according to his analysis, it is not a criticism, it is not limited to the structure of question and answer, it is not a manipulation, distortion, and does not exist in the absence of involvement of one of the parties ${ }^{10}$.

Because of the very nature of this notion, there are various types of dialogue, including internal (taking place in the consciousness of the individual) and external (going beyond the individual) ones ${ }^{11}$, within a specific group, within a community, between hierarchical entities. There is also a division according to the communication channel: direct, indirect (through new technologies such as the Internet or telephone); the group in which it takes place: private, between family members, between generations, and public in the context of social life $e^{12}$.

Thus, generational dialogue as one of the types of dialogue determines "the duration of social existence"13. Such a generational dialogue is expressed primarily in the transmission of legends, traditions and symbols. Relations between generations, on the other hand, provide content and narratives in which individuals, young people, grow up, and

municator of the principles of the language used. However, for generational communication, an additional vector is a cultural factor; E. Karmolińska-Jagodzik, Komunikacja międzypokoleniowa - rozważania wokót różnic kulturowych, «Studia Edukacyjne» 2012, no. 21, pp. 198-199.

8 M. Śnieżyński, Zarys dydaktyki dialogu, Kraków 1998, p. 169.

9 It should be added that the dialogue consists of replicas i.e. subsequent statements of individual interlocutors. This type of communication is considered a lively, interactive and dynamic way of speech in which participants can make statements by exchanging information; A. Załazińska, Niewerbalna struktura dialogu, Kraków 2006.

10 J. Grzybowski, Dialog jako forma duchowości w matżeństwie, Kraków 2009, p. 12.

11 Ibidem.

12 M. Rosochacka-Gmitrzak, A. Chabiera, 'Dialog międzypokoleniowy. Między idea a praktyka. Inspiracje'. Zasada równego traktowania, «Prawo i praktyk»2013, no. 10, pp. 5-7.

13 P. Ricoeur, Czas i opowieść, vol. I, Intryga i historyczna opowieść, Kraków 2008, p. 192. 
at the same time create the environment in which they function and age $^{14}$. This dialogue contains moments of unity that are interwoven with contradictions and confrontations of orientations ${ }^{15}$, aspirations ${ }^{16}$ and attitudes ${ }^{17}$.

Dialogue between generations creates a bond that leads to the creation of solidarity and a sense of mutual responsibility of generations. Such a bond transforms into activities that are created to meet the needs and care for the interests of all generations ${ }^{18}$.

The genesis of the changes in Georgian generational dialogue should be sought at the end of the $20^{\text {th }}$ century and now at the beginning of the $21^{\text {st }}$ century. These years brought about both social and cultural changes. This process was initiated by the social and political transformation, opening up the state to the international community, civilization leap, computerization and changes in values of the society. A particularly important social group in Georgia is the family, which also, under the influence of socio-political transformation has changed in the context of its role and status in society, as well as the internal structure itself. In addition, the development of new technologies in medicine has extended life, making families multigenerational. However, despite the multi-generational societies, the growing cult of youth denies the aging process, and as a result, old age is considered as a negative phenomenon. Physical and mental rejuvenation has pushed older people as well as their values and experience to the margins of society. This phenomenon has led to the international crisis of generational dialogue, reducing dialogue to a "youth monologue". This monologue is mainly associated with the "Western" lifestyle. As a result of the technological revolution and the rapid development of mass media, the younger generation have become "experts" of most aspects of life. And the older generation, which previously passed on family, local, and national history, traditions, ideologies

14 S. Biggs, A. Lowenstein, Generational Intelligence. A Critical Approach to Age Relations, London-New York 2011.

15 Orientation is an attitude in the phase of preparation for a specific activity or waiting for specific activities; J. Styk, System wartości a pokrewne kategorie życia społecznego, «Roczniki Nauk Społecznych»1987, vol. XV, pp. 126-140.

16 Aspiration is the interests, needs, and aspirations that an individual intends to pursue in a given time and conditions; B. Gołębiowski, Aspiracje, «Przekazy i Opinie» 1976, p. 8.

17 Attitude is permanent readiness, focus on the implementation of dominant aspirations, which is the driving force of such and no other behaviors of an individual towards all phenomena and objects of social reality; J. Styk, System wartości..., pp. 126-140.

18 Z. Woźniak, Solidarność międzypokoleniowa $w$ starzejącym się świecie - perspektywy i zagrożenia, «Ruch Prawniczy, Ekonomiczny i Socjologiczny» 2012, vol. 3, pp. 21-63. 
and a certain way of life to young people is positioned as a "student" rather than a "master" 19 .

However, generational dialogue was not affected only by the globalization that is currently taking place, the unification and the socio-cultural and technological revolution as well as the historical development of Georgia itself. The specificity of Georgia's historical development is not only due to the fact that the state has long been ruled by various, often hostile political forces, being reflected in its socio-cultural space, while political culture and political consciousness are fragmented, and their elements varied, sometimes contradictory. The specific and complex nature of Georgia's historical development has a significant impact on the generational dialogue in the sphere of creating and passing on political traditions. It is in the Georgian political tradition based on the transmission of values from generation to generation that the unchanging elements of historical experience are noticeable, which directly influence the motivation of political behavior and actions. These values create the current socio-political reality, and thus directly affect the democratization of the state.

The very concept of "tradition" is neither unequivocal nor simple, ergo is multifaceted and complex. In the socio-political dimension, tradition is the transmission of certain symbols, political myths, and stereotypes that contribute to the image of socio-political reality. Although such images may vary depending on the individual behavior of public figures, political events and the volatility of mass sentiments, they are distinguished by significant durability affecting attitudes and behavior. It should be added that they are associated with values such as freedom, equality, justice, stability, and order. They constitute the constitutive basis of political culture. They seem to be crucial goals that determine socio-political behavior ${ }^{20}$.

One of the levels of political tradition is the behavioral level, which expresses the mental values of an individual. Political values and norms influence the formation of political motivation and attitudes, finding reflection in certain behavior and actions. Part of the structure of traditions at the behavioral level are habits and behaviors that are spontaneous. According to M. Weber, this practice "is not guaranteed by external factors, which are in fact regulated voluntarily" [own translation] ${ }^{21}$. Cur-

19 E. Wiśniewska, Starsi i młodzi w dialogu pokoleniowym, «Społeczeństwo, edukacja, język» 2017, vol. 6, pp. 27-47.

20 Ibidem.

21 M. Weber, Osnovnyye sotsiologicheskiye ponyatiya, Moscow 1990, p. 634. 
rently, the Georgian society and its political culture are clearly tearing apart and weakening generational ties and creating a transitional character of relations, which means a departure from old values, but with visible nostalgia for the past ${ }^{22}$. Georgian political culture was shaped by the Soviet legacy - a strong leader who suppresses opponents. Compromise and consensus are not political goals. Each party, both the ruling party and the opposition, perceives their group / self (leader) as the sole owner of the truth about what is useful for the state and people and how political processes should develop, including democratization of the state.

\section{Political Tradition in Georgia}

Political traditions are "collected" and "stored" in certain forms of social and political experience that underpin political culture. Political tradition consists of stable images of reality and political power, while possessing the power to convey political awareness and behavior ${ }^{23}$. They form an integral part of the political and cultural context of society. $\mathrm{S}$. Eisenstadt formulated one of the definitions used in contemporary literature on the subject. Traditions, in his understanding, symbolize certain models of social order and are primarily composed of the level of social organization, individual behavior, and time itself ${ }^{24}$.

The time highlighted by Eisenstadt in the case of Georgia should be traced back to 1918-1921, when, as I have mentioned, the creation of a pro-European "political project" was imposed, and Georgia itself was the Democratic Republic of Georgia until 1921. This period awakened the pro-democratic and pro-European orientations of most Georgians. Then, at the end of the 1980s, Georgia entered a new stage of the socio-political system reform. Unlike most Western countries, in which the processes of political and social development took place naturally and were a kind of spontaneous modernization, in Georgia this phenomenon at all levels took the form of "catching up" or of political and social mobilization,

22 B. Gołębiowski, Dialog pokoleń. Studia nad socjologicznymi $i$ kulturowymi zagadnieniami dialogu $i$ nastęstwa pokoleń $w$ Polsce XX wieku, Warsaw 1980; A. Kamińska, Kategoria pokolenia $w$ badaniach nad spoteczeństwem $i$ kultura - przeglad problematyki, «Kultura i Historia» 2007, no. 11, http://www.kulturaihistoria.umcs.lublin.pl/archives/113 (10.05.2019); E. Karmolińska-Jagodzik, Komunikacja międzypokoleniowa - rozważania wokót różnic pokoleniowych, «Studia Edukacyjne» 2012, no. 21, pp. 196-197.

23 M. Wegner, Tradycja i kultura polityczna - wptyw tradycji na kulture polityczna PRL, «Zeszyty Naukowe. Seria 1 / Akademia Ekonomiczna w Poznaniu» 1988, no. 157.

24 S. N. Eisenstadt, Tradition, Change and Modernity, New York 1973, p. 139. 
and still continues so today. The key feature of Georgian modernization is that changes in the political system began on an unprepared social ground in the absence of the necessary political and cultural resources, which significantly complicated the transformation process and created the danger of achieving results contrary to those expected.

The experience of Georgia's political development has revealed that the formal adoption of a democratic model by the state does not guarantee a real transition to democracy. Political tradition in the period of transformation, due to the elements it transmits, can have both functional and dysfunctional significance for the political system.

Analysis of the mechanisms of the emergence and functioning of the political system of contemporary Georgia allows for a distinguishment of a number of features that largely result from the tradition of resistance in interaction between the society and state. Georgian political traditions are adapting to new socio-political conditions and the forms of their manifestations are still changing. These traditions became the foundation of the emerging political culture of society. The second important element affecting the structure of Georgia's political culture are its historical experiences and historical memory, which arise in the context of the national character and mentality, and these are stable and resistant to change. They remain in the layers of collective historical memory of people and significantly affect the formation of modern political values, norms, and behaviors.

Political behaviors and activities passed on as part of the generational dialogue are the result of building generational solidarity. They result from the potential of cultural and social communication of the older generation. This transmission of values can be considered as the basis for the development of society, the basis for political traditions, which are an important component of understanding democracy. According to D. Malazonia, generational dialogue in political tradition is a necessary condition for the progress of society and the political stability of the state ${ }^{25}$.

\section{Generational Dialogue or Generational Monologue?}

However, G. Nodia believes that intergenerational dialogue alone does not occur in any structured form of the society in Georgia. In most cases, it was assumed that socialization in the Soviet Union was

25 Expert interview with Professor D. Malazonia; Internet interview; February 18, 2019. 
unfavorable, and the younger generation had the privilege of not passing through this experience. A positive aspect is, therefore, the supposition that this generation has greater opportunities for development and self-expression not only thanks to democracy and free economy ${ }^{26}$. In opposition to G. Nodia, T. Turmanidze emphasizes the importance of generational dialogue in Georgia, describing it metaphorically as a kind of "clash of fathers and sons." This metaphor dates back to the late $19^{\text {th }}$ century. It meant an epistolary confrontation between younger and older generations of writers / public figures. However, such generational dialogues or clashes were suppressed, which was due to the fact that Georgia was part of the Russian Empire, and later the Soviet Union. Since regaining independence in 1991, when Georgia began to strive for democracy, all kinds of dialogues and disputes, including between different generations, have gained a new beginning in a more free environment, and the form of interaction between younger and older generations in Georgia has been more confrontational than conversational, which is visible even now. However, according to Turmanidze, the generational clash is not an important determinant of socio-political life in Georgia. Although after the Rose Revolution in 2003, the younger generation seemed to support democratic and institutional reforms, while the older tried to stick to Soviet practices. Later years, especially the period after the change of government in 2012, demonstrated that there were progressive and regressive elements in all generations of politicians, public figures and ordinary citizens, and constant struggle is more apparent between these elements of society than different generations ${ }^{27}$.

Z. Davitashvili claims that intergenerational dialogue is important because traditionally the younger generation takes into account the older generation. Representatives of the latter were born in the period when Georgia was part of the USSR - unlike the young, living in an independent state. So, the mentality of each generation is different, and it is important to engage in dialogue within different ways of thinking 28 . E. Shaverdashvili also underlines the importance of generational dialogue but notes that it is not a Georgian political or social tradition. According

26 Expert interview with Professor G. Nodia; the interview was conducted via the Internet; February 16, 2019.

27 Expert interview with Professor T. Turmanidze; the interview was conducted via the Internet; January 3, 2019.

28 Expert interview with Professor Z. Davitashvili; the interview was conducted via the Internet; February 18, 2019. 
to her, there is a lack of such a dialogue that would indicate a significant social change ${ }^{29}$.

And so, this flat and unconstant generational dialogue in Georgia was the reason for the creation of, among others, the Research-Intellectual Club, "Dialogue of Generations" (RICDOG). Its aim is to create a space where people from different generations will build harmonious relations with each other and create an intergenerational bond at various levels from a cultural to the socio-political level ${ }^{30}$. The club was founded on November 23, 2005, and it initially functioned as part of the Faculty of Humanities of the Akaki Tsereteli State University, and its main goal was to promote Russian language, culture and literature, and engage the new generation in scientific work. When the club expanded its area of activity and went beyond the university, new missions were developed related to the implementation of generational cooperation platforms in the field of civic activity. They were carried out, among other simulations regarding the participation of young and older generations, in local government and parliamentary structures. The first "Open Local Government" initiative is designed to develop leadership skills (leaders) among young people and to engage them in the decision-making process and in the development of cities and villages from which they come ${ }^{31}$. The second initiative implemented within the Club is a simulation of the "Kutaisi Youth Parliament" parliamentary session at the Ministry of Sport and Youth. It aims to demonstrate to young people through simulation, training and seminars how the parliament works, while supporting active participation of all generations in the education of future leaders ${ }^{32}$.

In addition, projects were organized to support the political activity of young people in cooperation with the older generation, such as

29 Expert interview with Professor E. Shaverdashvili; the interview was conducted via the Internet; February 9, 2019.

30 Generational meetings make it possible to try out new forms of cooperation between both generations, in addition to the existing forms of cooperation.

31 The initiative consisted of three phases. The first assumed the presentation of the theoretical foundation and ideological preparation for young people's political activities and behavior. The goal of this phase was to create a vision for the existing and alternative "political environment" through informal education methods, guests from the older generation, group and individual tasks of representatives of both generations, ideological statements and various activities. The next phase was to simulate the election of the mayor, his administration and city council; зmÿ "ossmbsons cosmmgl" https://www.ricdog.org (1.03.2019).

32 Ibidem. 
the "Political Party" and "Advanced Reforms, Advanced Civil Society"33 with the financial support of the LEPL Electoral Systems Development, Reform and Training Center ${ }^{34}$.

The project fills a gap in intergenerational dialogue. This means that not only scientists notice the lack of dialogue, but also the society itself that participates in and supports the project. However, this project is just the beginning of supporting generational dialogue - a dialogue that can become an important element of Georgian political tradition in the coming years.

\section{Conclusions and Nudging Discussion on Generational Dialogue in Georgia}

In a nutshell, democratization has affected not only the political, but also social structures. The transformation of society begins with the transformation of generations. An interesting social concept related to political transformation was pointed out by V. Papava. He highlighted that the transformation began with homo sovieticus ${ }^{35}$ and homo transformaticus ${ }^{36}$

33 The "Advanced Reforms, Advanced Civil Society" project aims to promote social policy reforms in the Eastern Partnership member states. The above programs and project are designed to support intergenerational dialogue and pass on the experience of the older generation in the field of political activities and thus to activate young people to active participation in socio-political life; 3 myz "osmbsons coosmmgle" https://www.ricdog.org (1.03.2019).

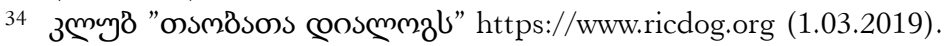

35 According to V. Papava, homo sovieticus born in 1930-1945 or the "Silent Generation" according to the Anglo-Saxon standards of research on generations. The term was first used by The Times in 1951, to describe people born in 1928-1945, people who were afraid to "speak out loud." According to the Pew Research Center, these are people born in 1928-1945, according to the Resolution Foundation 1926-1945, Strauss and Howe 1925-1941 for the Canadian society; https://www.researchgate.net/publication/233466490_Profiling_the_Silent_Generation.

36 According to V. Papava, the generation born in the years $1970-1990$ is referred to as homo transformaticus - which means people who are not able to completely get rid of the fear of the state, and thus slowly begin to pursue their own private interests and benefit from it. A homo transformaticus is a man who is partially developed, based on privatization and mainly on newly formed private structures. Such people are still afraid of the state. They still try to maintain their dependence on the state and expect its help. They gradually adjust to the rules of the market economy. Moreover, by analogy, the Anglo-Saxon terms "baby boomers" and "generation x" coincide with my assumption. According to researchers, the "baby boomers" grew up in the period of socio-political transformations and economic development based on a free market economy, which were a barrier for this generation. However, this generation is already referred to as the transition generation, a generation of individualists, 
to homo oeconomicus ${ }^{37}$. This concept presents a wide range of attitudes towards the political, economic, and social spheres. One can also distinguish a new generation, the youngest one, "generation Z"38, or paradox generation that is, as I want to emphasize, an internally conflicted generation, placed between tradition (values of previous generations) and modernization (values flowing from the West). And this radical transformation of generations affects the generational dialogue in Georgia.

According to Polish theorists and researchers, the generational dialogue is a particularly important element of generational existence. However, the current dialogue, as I have stated, is interrupted, flat and unconstant, which highlights the differences between older generations and the youngest one, the internally conflicted generation. These differences are visible at both public and private levels. The approach of the older generation and the younger one to democracy itself, the free market and international affairs is definitely different. The same applies to the approach to starting a family, gender hierarchy in the family, sex life, religion, and professional issues. It is the "breaking-up" of this dialogue that causes these differences to deepen and polarize the society. In Georgia, there is still a divergence in opinions about the path that has been chosen in the context of democratic change. These changes took place and continue in the conditions of internal political struggle for the shape of the political system of the state, as well as numerous discussions focusing on democracy itself and the democratization of life in that state between the generations. The process of implementing democracy is hampered by a sense of uncertainty, which is accompanied by the soci-

people who value independent work, with a recognition of authorities and the need of support in making any changes "inherited" from the previous generation; and in the literature on the subject, "generation x" is referred to as "stability seekers"; V. Papava, Necroeconomics - A Phenomenon of the Post Communist Period of Transition, "Obshchestvo i ekonomika» 2001, no. 5; B. Hysa, Zarządzanie różnorodnościa pokoleniowa, «Zeszyty Naukowe Politechniki Śląskiej» 2016, no. 97.

37 Homo oeconomicus in Anglo-Saxon terminology functions as "generation Y," which grew up in the age of computerization and the development of the Internet. They are the people who are open to the world, without socio-political limitations, with the possibility of a career and economic migration. People of this generation need independence, but they are looking for their mentors. They invest in themselves and demonstrate reluctance towards long-term obligations.

38 The generation born in 2000 is "generation Z," that is, the "connected" generation - connected to the network, to the Internet. They cannot function through electronic media as it is part of their everyday life. They are mobile people, open to other cultures and open to change; B. Hysa, Zarządzanie różnorodnościa pokoleniową, «Zeszyty Naukowe Politechniki Śląskiej» 2016, no. 97. 
ety's fears of uncritical implementation of new systemic solutions, not fully known and carrying phenomena observed in Western countries, not fully desirable and accepted. In addition, the lack of understanding of the functioning of democratic institutions and the deep cleavage of the multi-ethnic population mean that democratic values are implemented to a limited extent in Georgia.

It is worth noting that this dialogue is not only affected by the internal issues of radical generational transformation, the generations' values, but also by the new values that have been promoted and implemented from the outside, from the Western world mostly, in the context of socio-political democratization. As a result, the current society, consisting of four generations, has adopted some values and patterns of behavior from the previous ones, but only some because of the flat and unconstant generational dialogue. According to G. Godlewski, current generations living in the world: "(...) have their own dictionaries and symbol constellations, cognitive categories and patterns of feelings, forms of communication and friendship models, myths and future projects. These are not just different environments or social strata - they are different cultures" [own translation $]^{39}$. The same applies to the Georgian society.

Yet, the question arises, why is generation dialogue passed down as a political tradition considered to be of a greater importance? Traditions passed down from generation to generation in the form of dialogue are an important issue in the context of the future of the state. Because the young generation, shaped by a number of factors, including, but not limited to, family and traditions passed down from the older generation, will constitute Georgia's future political elite. It is the young people in the political processes taking place in both democratic countries and totalitarian and authoritarian systems that constitute an important and special part of society. This group is considered to be the most inspiring nation as a whole. According to $\mathrm{H}$. Marcuse, the factors of social change in the modern world are youth (students), women and the Third World society. His assumption concerned primarily the moral and cultural revolution that has an impact on political processes. When it comes to transforming the entire socio-political system, young people are an important, though not the main actor in this process ${ }^{40}$.

39 W. Adamski, Młodzież $i$ społeczeństwo, Warsaw 1976.

40 G. Godlewski, Animacja i Antropologia, [in:] G. Godlewski, I. Kurz, A. Mencwel, M. Wójtowski (eds.), Animacja Kultury. Doświadczenie i przyszłość, Warsaw 2002, p. 60. 
It is generational dialogue, generational coexistence, cooperation and solidarity that can constitute a "defensive wall" in the current crisis of democracy. The crisis in the "Western" world, and at the same time the transition to the third industrial revolution, global renegotiation of economic and military powers, deep internal and external attacks on liberal democracy, acceleration of climate change and the coronavirus pandemic in 2020, changed the trajectory of democracy also in the South Caucasus. In addition, for countries that are currently undergoing democratization, such as Georgia, there is uncertainty as to whether the choice was right in the face of the crisis of democratic legitimacy. And the unconstant dialogue intensifies this uncertainty and deepens generational differences, along with the polarization in relation to the chosen "political project." Yet, the current socio-political situation of Georgia (related to democratic changes first after 1991, later after the Rose Revolution in 2003, and now in the context of many demonstrations in defense of democracy) represents a new opening in generational dialogue, although it is not part of the Georgian political tradition, but it can become one.

\section{Bibliografia}

Adamski W., Młodziė̇ i społeczeństwo, Warsaw 1976.

Biggs S., Lowenstein A., Generational Intelligence. A Critical Approach to Age Relations, London-New York 2011.

Chedia B., Georgia: The Long Journey from the Byzantine Empire to the European Union, http:// www.eastbook.eu/en/2012/01/09/georgia-the-long-journey-from-the-byzantine-empireto-the-european-union (1.05.2020).

Eisenstadt S. N., Tradition, Change and Modernity, Nowy Jork 1973.

Godlewski G., Animacja i Antropologia, [in:] G. Godlewski, I. Kurz, A. Mencwel, M. Wójtowski (eds.), Animacja kultury. Doświadczenie i przyszłość, Warsaw 2002.

Gołębiowski B., Dialog pokoleń. Studia nad socjologicznymi i kulturowymi zagadnieniami dialogu i następstwa pokolen w Polsce XX wieku, Warsaw 1980.

Grzybowski J., Dialog jako forma duchowości w małżeństwie, Kraków 2009.

Hysa B., Zarządzanie różnorodnościa pokoleniową, «Zeszyty Naukowe Politechniki Śląskiej» 2016, no. 97.

Jagielski W., Dobre miejsce do umierania, Warsaw 2008.

Kamińska A., Kategoria pokolenia w badaniach nad spoteczeństwem i kultura - przeglą problematyki, «Kultura i Historia» 2007, no. 11, http://www.kulturaihistoria.umcs.lublin.pl/ archives/113 (10.05.2019).

Karmolińska-Jagodzik E., Komunikacja międzypokoleniowa - rozważania wokót różnic kulturowych, «Studia Edukacyjne» 2012, no. 21.

Nodia G., Georgia: Dimensions of Insecurity, [in:] R. Legvold, B. Coppieters (eds.), Statehood and Security: Georgia after the Rose Revolution, Cambridge 2005.

Ricoeur P., Czas i opowieść, vol. I, Intryga i historyczna opowieść, Kraków 2008. 
Rosochacka-Gmitrzak M., Chabiera A., Dialog międzypokoleniowy. Między idea a praktyka. Inspiracje. Zasada równego traktowania, «Prawo i praktyka» 2013, no. 10.

Skiert-Andrzejuk K., Georgia's Political Brand in the European Union: Building the Political Product and the Political Brand, «Nowa Polityka Wschodnia» 2018, vol. 4, iss. 19.

Śnieżyński M., Zarys dydaktyki dialogu, Kraków 1998.

Styk J., System wartości a pokrewne kategorie życia społecznego, «Roczniki Nauk Społecznych» 1987, vol. XV.

Weber M., Osnovnyye sotsiologicheskiye ponyatiya, Moscow 1990.

Wegner M., Tradycja i kultura polityczna - wptyw tradycji na kulture polityczna PRL, «Zeszyty Naukowe. Seria 1 / Akademia Ekonomiczna w Poznaniu» 1988, no. 157.

Wiśniewska E., Starsi i młodzi $w$ dialogu pokoleniowym, «Społeczeństwo, edukacja, język» 2017, vol. 6.

Woźniak Z., Solidarność międzypokoleniowa $w$ starzejącym się świecie - perspektywy i zagrożenia, «Ruch Prawniczy, Ekonomiczny i Socjologiczny» 2012, vol. 3.

Załazińska A., Niewerbalna struktura dialogu, Kraków 2006. 